\title{
Genetics of growth in the normal child
}

\author{
Roland Pfäffle \\ Department of Paediatrics, University of Leipzig, 04317 Leipzig, Germany \\ (Correspondence should be addressed to R Pfäffle; Email: rpfaeffle@medizin.uni-leipzig.de)
}

\begin{abstract}
Although an impaired longitudinal growth is a part of many chromosomal aberrations and a variety of single gene mutations, rarely is it the only symptom of patients with genetic syndromes. Otherwise, in a healthy child, the influence of parental height on the adult height of their children is well established. Although this genetic influence can be easily demonstrated by statistics and is observed over generations, the hormonal and metabolic factors that control the quantitative marker 'growth' remain difficult to establish. Genetics has used different approaches to address this question. Linkage studies so far have yielded some new, but partially conflicting, data about the key factors that influence growth and finally adult height. In contrast, the examination of 'candidate genes' has been very fruitful in identifying those genes that are responsible for some well-defined hormonal deficiencies in patients with severe short stature.

As the systematic examination of such genes in short children with and without hormonal deficiencies has become feasible, it appears that the phenotypic appearance of some of these disorders is variable to an extent that makes it difficult to differentiate them from a 'short normal child'. Both the 'candidate gene' and the 'reverse genetics' approaches using linkage analysis on a whole genome scale have produced results that have already furthered our understanding of the complex mechanisms that influence growth. Both the approaches have come closer to each other, but so far they have not produced the overlap of evidence that one had initially anticipated.
\end{abstract}

European Journal of Endocrinology 155 S27-S33

\section{Introduction}

Abnormal growth is a common reason for referral to a paediatric endocrinologist, but only a small proportion of patients have an identifiable pathological cause for their small stature, such as a growth hormone $(\mathrm{GH})$ deficiency (GHD). This leaves the main proportion of patients with the diagnosis of idiopathic short stature (ISS), despite the fact that an intense medical workup has been performed to exclude a great body of metabolic disorders or environmental factors that can impair growth.

This leaves us with the question of what really influences growth and final height in these patients, and whether there is an identifiable margin between normal and abnormal. Many of our diagnostic approaches towards causes of short stature focus on the question of whether they are treatable or not. This review, however, will focus on which factors primarily influence physiological growth.

Environmental and metabolic factors are important regulators of the neuroendocrine axes, but these

This paper was presented at the 4th Ferring Pharmaceuticals International Paediatric Endocrinology Symposium, Paris (2006). Ferring Pharmaceuticals has supported the publication of these proceedings. influences are superimposed upon a substantial degree of genetic control. It has been known for long time that parental height directly influences the child's growth, and algorithms to calculate target height, which is the mean of parental height corrected by a factor that accounts for the sex differences in growth, were developed in the very early days of auxology. Much of our everyday height prediction still relies on midparental height despite the fact that generations of children have continuously grown taller and taller. They have demonstrated a considerable increase in their mean height in the past decades due to the well-established secular trend. However, the correlation of their final height to midparental height remained stable. Analyses of adult height in families and studies of twins indicate that the heritability for the quantitative marker adult height ranges between 75 and $90 \%$. Most of the estimates being above $80 \%(1-3)$. This means that roughly $20 \%$ of adult height is due to environmental factors. Indeed, this genetic dependency of growth and final height is observed even under circumstances of prolonged states of mal- or over-nutrition (4).

Statistically, adult height is normally distributed within a given population. This simple fact per se makes it very unlikely that the variation of adult height is the consequence of a genetic variation of a single 
locus that follows a classic form of Mendelian inheritance. Rather, it must be due to the additive effects of multiple genes. In this respect, adult height is expected to be a complex trait. Modern molecular genetics and new statistical approaches potentially provide powerful methods to identify the genes that are most likely to attribute to the process of growth and thereby final height.

In general, three major approaches have been followed to find the genes that underlie complex traits. There is an approach of resequencing candidate genes that are known to influence the process of growth by their physiological characteristics, there are genome-wide linkage analyses and finally there are association studies.

\section{Examination of candidate genes}

Examining the variability of genes that are known to contribute to the process of growth possibly provides important information on how much these factors contribute to differences in adult height.

So far, we are already aware of numerous single gene defects that can affect growth. A query in the Online Mendelian Inheritance in Man database that contains the term 'short stature' will provide more than hundred syndromes that are associated with short stature. Paediatric endocrinology will obviously focus on those factors that are involved in the hormonal regulation of growth, i.e. factors that influence the complex regulation of the secretion within the hypothalamopituitary growth axis (see Fig. 1).

Starting from the gene that most evidently represents the hormonal control of growth, the human GH1, it was possible to find pathogenic mutations in almost every member of the signal cascade within the hypothalamopituitary growth axis (Fig. 1; Table 1).

The mutations in the GH1 gene that were initially described were gene deletions, which followed an autosomal recessive way of inheritance (5-7). However, more detailed analyses revealed various mutations within the GH1 gene that followed both an autosomal dominant or a recessive trait (7-9). Overall, the incidence even within a well-selected population of patients with isolated growth hormone deficiency (IGHD) of these mutations is rather low $(<5 \%)$.

Factors that directly influence $\mathrm{GH}$ regulation have also been studied extensively like the growth hormonereleasing hormone receptor (GHRHR) and mutations were identified similarly causing autosomal recessive IGHD $(10,11)$. Interestingly, no mutations within the GHRH have been identified so far (12).

Following the $\mathrm{GH}$ axis downwards to the level of $\mathrm{GH}$ action on target tissue, genetic defects were identified within the possible candidate genes, always in a similar order. First, mutations were detected that affected the growth hormone receptor (GHR), which resulted in the clinical syndrome of $\mathrm{GH}$ resistance or Laron type dwarfism (13). Most of these patients have a severe form of short stature with high GH and low insulin-like growth factor-I (IGF-I) levels, accompanied by symptoms like a thin and wrinkling skin, sparse hair and a high-pitched voice. Patients with Laron's syndrome overall are very rare $(\ll 1 \%)$ and despite the fact that mutations within the GHR have been identified that are associated with a milder phenotype resembling patients with ISS $(14,15)$ genetic variations within the GHR are unlikely to account for a major proportion of the genetic

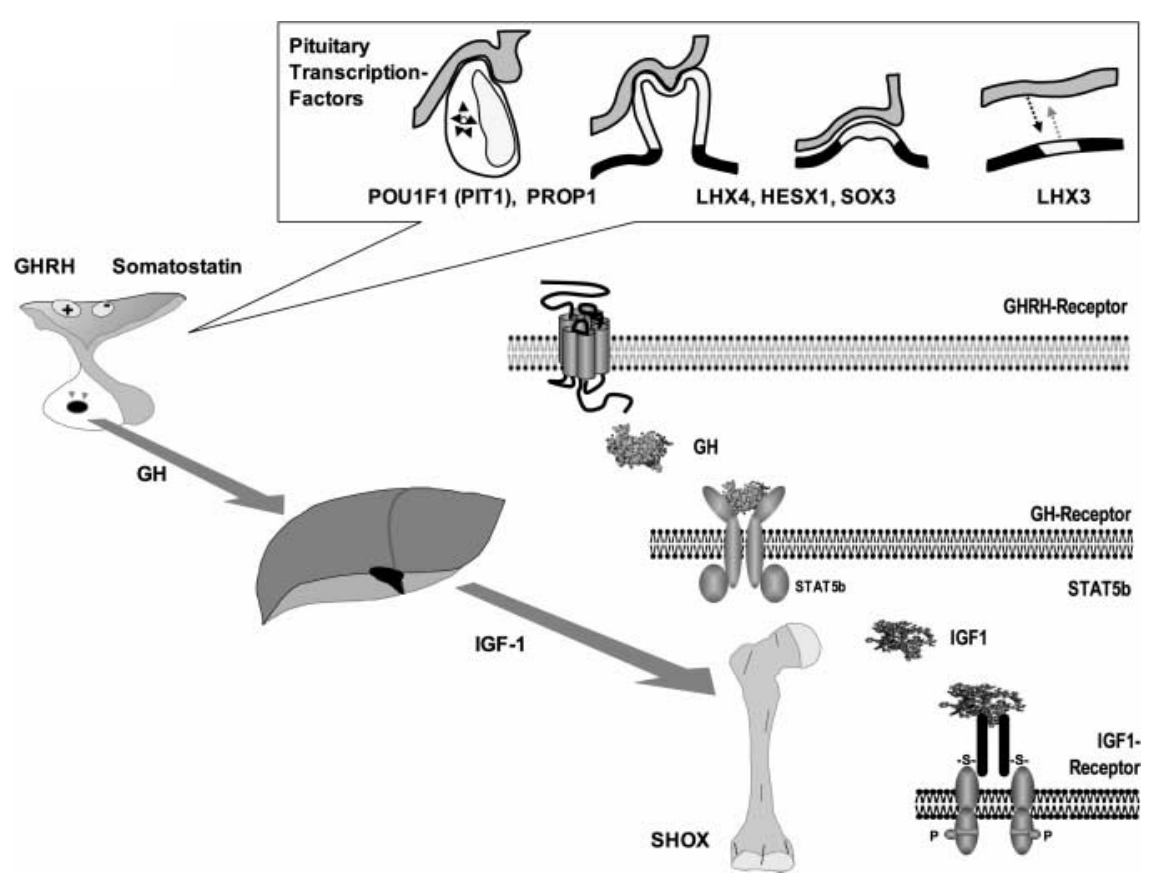

Figure 1 Schematic view of the hypothalamo-pituitary growth axis and the factors involved. Most of the factors have been tested for their relevance by the candidate gene approach (see Table 2). Pituitary transcription factors control pituitary development in a sequential order. GH release is controlled by the hypothalamic release of somatostatin and GHRH. All the defects within the GH-receptor or downstream factors result in various states of $\mathrm{GH}$ resistance. SHOX is not directly involved in the $\mathrm{GH}$-axis. Defects are found in idiopathic short stature, short stature related to Turners syndrome and Leri Weill syndrome. Whole genome linkage analyses implicate that it may hold a major influence also on normal growth variation. 
Table 1 Factors influencing the hypothalamo-pituitary growth axis and their location within the genome.

\begin{tabular}{|c|c|c|}
\hline Member of axis & $\begin{array}{l}\text { Established mutations } \\
\text { result in }\end{array}$ & $\begin{array}{l}\text { Chromosomal } \\
\text { location }\end{array}$ \\
\hline \multicolumn{3}{|c|}{ Pituitary transcription factors } \\
\hline SOX3 & MPHD $(+/-)$ & $\mathrm{X}$ q26.3 \\
\hline LHX3 & MPHD $(+/-)$ & 9 q34.3 \\
\hline LHX4 & MPHD $(+1-)$ & $1 \mathrm{q} 25.3$ \\
\hline HESX1 & MPHD $(+1-)$ & 3 p14.3 \\
\hline PROP1 & MPHD & 3 p11.2 \\
\hline POU1F1 & MPHD & 5 q35.3 \\
\hline \multicolumn{3}{|c|}{ Hypothalamic factors } \\
\hline GHRH & - & 20 q11.2 \\
\hline Somatostatin & _ & 3 q27.3 \\
\hline \multicolumn{3}{|l|}{ Pituitary factors } \\
\hline $\mathrm{GH}$ & IGHD & 17 q23.3 \\
\hline GHRH receptor & IGHD & 7 p14.3 \\
\hline \multicolumn{3}{|c|}{ Factors in $\mathrm{GH}$-signal transduction } \\
\hline GHR & GH Resistance & 12 q23.2 \\
\hline IGF-I & IUGR, GH Resistance (+) & \\
\hline Stat5b & IUGR, GH Resistance (+) & 17 q11.2 \\
\hline IGF-I receptor & IUGR, GH Resistance & $15 \mathrm{q} 26.3$ \\
\hline \multicolumn{3}{|l|}{ Others } \\
\hline SHOX & Short stature $(+/-)$ & X p22.3 \\
\hline
\end{tabular}

For most factors listed, gene mutations have been reported that lead to multiple pituitary hormone deficiency (MPHD), isolated growth hormone deficiency (IGHD) and GH resistance with or without intrauterine growth retardation (IUGR). Many genetic defects are consistently $(+)$ or inconsistently $(+/-)$ associated with other functional or morphological symptoms that are not directly associated with growth regulation.

variability in adult height. Similarly, recessive mutations within Stat5, a protein associating with the GHR and important for signal transduction have been described in patients with intrauterine growth retardation (IUGR) and postnatal growth retardation who showed GH insensitivity and an immunodeficiency (16, $17)$. In contrast, a deletion of the IGF-I gene was found to be associated with intrauterine and postnatal growth failure associated with mental retardation and deafness (18). Finally, mutations within the IGF-I receptor (IGFIR) have been found to be associated with IUGR (19, 20), again these mutations have been identified only in few patients so far with the rare hormonal constellation of high IGF-I serum levels in the face of growth failure. At the first sight, it therefore seems unlikely that variations of this receptor will account for a major part of the genetic variance of adult height.

Factors that coordinate the embryological development of organs that participate in the regulation of growth will also profoundly influence adult height. Today, the network of transcription factors that regulate pituitary development is well established. Mutations have been identified in pituitary factors like PIT1 (POU1F1) (21) PROP1 (22), HESX1 (23) or LHX3 (24) and LHX4 (25) which result in various forms of multiple pituitary hormone deficiency (MPHD). They are primarily associated with severe forms of short stature. Despite theses initial observations, a systematic genetic analysis of patients with MPHD revealed a variability of the phenotypic manifestation caused by some mutations within these pituitary transcription factors.

As an overall rule, the earlier during embryogenesis of the pituitary the affected factor is expressed, the more complex and variable the resulting phenotype can be. This refers to the number of different pituitary hormone lines that are affected, the severity of the hormone deficiencies and possible associations with further morphological and structural abnormalities. However, there is also a greater variability in the severity of phenotypic manifestation, if the mutation does not result in a complete loss of function of the gene involved. This means that minor mutations in some of these transcription factors like (LHX3, LHX4 and HESX1) may result in a syndrome that could be characterised by an inadequate GH secretion alone. Although poor candidates at first sight, these genes theoretically could account for some of the variability of human adult height.

Despite the fact that the candidate gene approach has established the genetic link between many of the hormonal factors and genetic forms of growth failure, it remains difficult if not impossible to quantify their influence on 'normal' adult height. This is mainly due to two facts: the technical difficulty to make statistical analyses within a population about conditions with extremely rare manifestations, and the systematic error, which inherently occurs when 'candidate patients' with a distinct phenotype are examined for the occurrence of mutations in a candidate gene.

\section{The examination of pedigrees, segre- gation analysis and linkage studies}

A 'segregation analysis' is the formal entry to all following analyses that try to identify genetic regions within the entire genome that could regulate the quantitative marker adult height. It permits to identify the general patterns of inheritance, to determine the degree of familiarity and sometimes even to estimate roughly the complexity, meaning the number of genes, which underlies a quantitative trait like height is.

Such segregation analyses require families rather than individuals where the quantitative trait adult height is measured in several generations and these data are statistically analysed and compared with other families. A computer program like statistical analysis for genetic epidemiology (SAGE) can calculate correlation coefficients $\left(r^{2}\right)$ of height from the sums of squares and cross products in relative pairs. It has been calculated that in first degree relative pairs (parent-child) $r^{2}=0.4$, in second degree relative pairs (grandparent-child) $r^{2}=$ 0.2 and in third degree relative pairs (first cousin-child) $r^{2}=0.06$ (26). This reflects the high relevance that the genetic input has on individual growth (see Table 2). This study was performed in 200 Dutch families. Further analysis in this population suggested that few 
Table 2 Correlation coefficients of height (adjusted for age and sex) among various relative pairs (age $>16$ years), data derived from 200 Dutch families (26).

\begin{tabular}{lcc}
\hline Relationship & $\begin{array}{c}\text { Number of } \\
\text { pairs }\end{array}$ & $\begin{array}{c}\text { Correlation } \\
\text { coefficient }\end{array}$ \\
\hline First-degree relatives & 1354 & \\
Parent-offspring & 370 & 0.41 \\
$\quad$ Mother-daughter & 309 & 0.49 \\
$\quad$ Mother-son & 368 & 0.41 \\
$\quad$ Father-daughter & 307 & 0.32 \\
$\quad$ Father-son & 695 & 0.45 \\
Siblings & 197 & 0.41 \\
$\quad$ Sister-sister & 347 & 0.43 \\
$\quad$ Sister-brother & 151 & 0.38 \\
$\quad$ Brother-brother & & 0.44 \\
Second-degree relatives & 258 & 0.21 \\
Grandparent-grandchild & 559 & 0.25 \\
Avuncular & & 0.06 \\
Third-degree relatives & 405 & 0.16 \\
$\quad$ First cousin & 276 & \\
Unrelated spouses & & \\
\hline
\end{tabular}

mainly recessive allele(s) have major effects on height and are modulated by multiple other genes.

For 'linkage analysis', multiplex families are similarly required. The quantitative marker adult height seems ideally suited for such an analysis, because it is stable once the person has grown up and it is technically easy to obtain. It just means to type a genome-wide set of polymorphic informative markers in pedigrees to find the regions within the whole genome that are inherited more often than expected in relatives with similar phenotypic characteristics (small or tall stature). This approach has the advantage that it is an unbiased genome-wide search for causal genes and it has been successfully employed in the identification of numerous single-gene disorders.

However, in complex traits, the power of linkage studies can easily be impaired. This is due to the fact that the effect of any individual genetic variant most likely will be modest if several genes are involved. The influence of environmental factors will impair the power of the analysis and inaccurate phenotyping in more complex disorders can severely interfere with the result. From these considerations, however, the complex trait growth seemed rather well suited for a linkage analysis approach (27). The phenotype (adult height) is stable, environmental influence at least seems limited, and segregation analysis suggested the presence of a limited number of genes with a major impact on growth.

In the initial attempt, Hirschhorn et al. analysed genome-wide linkage data from four different populations from Finland, Sweden and Quebec and found three regions with significant evidence of linkage to stature: 7q313-36, 12p11.2-q14 and 13q32-33. An additional region was found at chromosome 6q24-25. A following study of another group found regions with limited significance at chromosomes 5q31, Xp22 and
Xq25 in individuals from Europe (28) and thereby no overlap with the initial report. A third study at least overlapped on genes $6 \mathrm{q} 25$ and 12q1 with the report by Hirschhorn and additionally found chromosome $9 \mathrm{p} 1$ to be significantly linked with adult height (26). Finally, Perola et al. found significant regions at chromosomes 7 pter and 9q, which overlapped at least partially with regions by two former analyses (29).

The partially conflicting results of these initial attempts to identify the chromosomal regions relevant for human growth seemed confusing and it was difficult to determine whether they were due to the different ethnicity of the populations studied, different sample sizes that ranged between 50 and 200 families or differences in the statistical approach.

A number of 'second generation' linkage analyses on growth, which mainly involved larger sample sizes (up to 434 pedigrees and 4130 individuals (30)) are narrowing down on a smaller number of genetic regions that are associated with body height. Regions identified here attain high significance levels and can be replicated in various populations $(28,30)$. Among the regions with the highest significance are chromosomes 9q22, Xq24 and Xp22 (see Table 3).

This does not mean that other loci remain insignificant and do not contribute to final height, they are more likely to be part of the polygenic background of adult height, genes, which per se have a smaller influence. During the initial studies several loci had occurred that contained genes, which were 'old bodies' for paediatric endocrinologists: the GH1 gene, the GHRHR gene and the LHX3 gene. However, repeated analysis did not support major significance. The fact that they are no longer part of the exclusive family of major growth determining genes does not diminish their role in certain disease states like IGHD or MPHD, they probably just do not determine the variability of physiological adult height to any greater extend.

Now, which genes can be deduced from the present studies as the major determinants of normal growth? Even in the face of convincing evidence of such linkage, it is difficult to progress from this level down to the level of identifying a causal gene or a causal sequence variation. The typical region a linkage analysis can narrow down to in complex traits is $20 \mathrm{cM}$ long (centimorgan $=1 \%$ recombination probability), which corresponds to an average of 20 megabases. In such a stretch of DNA numerous genes will be located. Even if the right gene is picked in such a region, the proof that the variants, which have been found are causal, remains somewhat difficult. This, among other reasons is due to the fact that the variants are not necessarily easily detectable as simple nonsense, frameshift or missense mutations, which usually underlie single gene disorders.

So far it is interesting, however, that within two of the three regions with the highest significance, $9 q 22$, and 
Table 3 Reported linkage between chromosomal localisation and adult-height.

\begin{tabular}{|c|c|c|c|c|}
\hline \multicolumn{2}{|c|}{ Chromosome } & \multicolumn{2}{|c|}{ Association reported by linkage analysis $(\bullet=1$ report $)$} & \multirow[b]{2}{*}{$\begin{array}{l}\text { Known growth related gene(s) } \\
\text { located in region }\end{array}$} \\
\hline No. & Location & $\begin{array}{c}\text { In first generation studies } \\
(<200 \text { pedigrees sample size })\end{array}$ & $\begin{array}{l}\text { In second generation studies } \\
\text { (>200 pedigrees sample size })\end{array}$ & \\
\hline 1 & P13 & - & & Cathepsin K \\
\hline 2 & Q24 & - & & \\
\hline 2 & Q36 & - & & \\
\hline 4 & P16 & $\bullet \bullet$ & & FGF3R \\
\hline 5 & Q14 & - & & \\
\hline 5 & Q22 & - & & \\
\hline 6 & $\mathrm{P} 21$ & - & & \\
\hline 6 & Q25 & $\bullet \bullet$ & & Oestrogen receptor \\
\hline 7 & P14 & • & & GHRH receptor \\
\hline 9 & P1 & - & & \\
\hline 9 & P13 & •• & & \\
\hline 9 & P22 & - & & \\
\hline 9 & Q22 & $\bullet \bullet$ & - & ROR2 \\
\hline 9 & Q32-34 & •• & & LHX3 \\
\hline 10 & Q26 & - & & \\
\hline 11 & Q25 & - & & \\
\hline 12 & P12 & - & & \\
\hline 12 & Q1 & - & & \\
\hline 14 & Q23 & - & & \\
\hline 17 & Q22-23 & •• & & Col1A1, GH1 \\
\hline 17 & P13 & - & & \\
\hline 22 & Q12 & - & & \\
\hline$x$ & P22 & & - & SHOX \\
\hline $\mathrm{X}$ & Q13 & - & & \\
\hline$x$ & Q23-24 & $\bullet \bullet \bullet$ & - & \\
\hline
\end{tabular}

Significant linkage reported from studies with populations with less than 200 pedigrees is called first generation linkage. The second generation studies cited here contained $>200$ pedigrees (434 pedigrees in the publication by (30). No logorithmic odds ratio-scores are given because they differed considerably between the different studies due to sample size and the statistical approach used. This list therefore also reflects the interpretation given by the different authors.

Xp22 two candidate genes are located, which are related to growth. $9 q 22$ contains a gene called ROR2, receptor tyrosine kinase-like orphan receptor 2 , which is selectively expressed in chondrocytes and required for cartilage and growth plate development. Mutations within this gene cause Robinow syndrome, a severe skeletal dysplasia with generalised shortening of limbs and segmental defects of the spine $(31,32)$.

Xp22 contains the SHOX gene that again is linked with skeletal development. Mutations in the SHOX gene have a polymorphic phenotype and result in ISS, short stature found in Turners Syndrome, Leri Weill syndrome and Langer Mesomelic Dysplasia (33).

\section{Seeking proof in the broader, unrelated population, association studies}

Association studies constitute a complementary method, which helps to identify common variants with only a modest genetic effect. In contrast with whole genome linkage analyses, they are hypothesisdriven, returning to the old fashioned way of doing research. They are simple in principle: the frequency of a genetic variation is measured in affected individuals and in controls. If the frequency significantly differs between the two groups, an association can be assumed. For the study of the quantitative trait growth, two groups have to be formed: people who have short stature and people with normal height. Despite their simple approach, association studies have numerous drawbacks. There are the inherent difficulties in the stratification of the populations studied, the temptation of these studies to test multiple hypotheses at one time and the possibility that the marker examined is not perfectly correlated with the causal variant $(34,35)$. This makes it conceivable why association studies have not been consistently reproducible. In a systematic evaluation of association studies, which had established 166 associations between common diseases and common variants, only six of these associations were reproducible in more than $75 \%$ of the published reports (36). Nevertheless, more than $50 \%$ of the studies were replicable at least once.

Association studies rely on genes or loci that previously have been identified as candidates, either by a candidate gene approach or via linkage analyses. Modern high-throughput technologies in genotyping and the knowledge of the human genome make these studies more and more powerful as a large set of genes in a large population can be studied.

Candidate genes of the hypothalamo-pituitary growth axis that underwent association analysis are the IGF-I gene and the GHR gene. 
Three highly polymorphic markers lie close before, within and behind the IGF-I gene. The so-called IGF-I$192 \mathrm{bp}$ allele was found to be correlated with an increased risk for myocardial infarction, type 2 diabetes, lower serum IGF-I levels and a reduced birth weight (37, 38). In other studies, Frayling et al. did not find this locus to be associated with diabetes type 2 , differences in IGF-I levels or adult height (39). In a third study, the authors found an association between this marker birth weight, head circumference and IGF-I levels (40). The conflicting results of these reports should not be discouraging as the problems of association studies are well established, but also should be able to overcome.

Recently, another association study has gained even broader interest among paediatric endocrinologists. There is a common polymorphism within the $\mathrm{GH}$ receptor. Exon 3 of the GHR gene can be present or absent due to the fact that it is flanked by two highly homologous sequence-stretches (41). Analyses of this polymorphic marker showed that the shorter form of the GHR is associated with a better growth response in children with small for gestational age or ISS, who receive a relatively high dose of recombinant $\mathrm{GH}$ to promote growth (42). So far, these findings have been confirmed by one study (43) and another study showed a better growth response in children with IGHD who received an even lower dose of recombinant human $\mathrm{GH}$ (44). However, in our own population of patients with IGHD, we were not able to establish such a correlation.

\section{Conclusion}

The identification of the genes that influence the complex trait height is more complex than anticipated. However, both the 'candidate gene' and the 'reverse genetics' approaches using linkage analysis on a whole genome scale have produced results that already have furthered our understanding on the complex mechanisms that influence growth. Both the approaches have come closer to each other, but so far they have not produced the overlap of evidence that many of us had anticipated before the 'fishing cruise' had started. As such, they so far seem complementary to each other. The major benefit of the candidate gene approach is that it will allow us to confirm a diagnosis in certain identifiable growth disorders and, thereby, will help us to refine our treatment strategies. The data obtained by linkage analyses at present will be a target of future affirmative studies if feasible either by the candidate gene approach or by association studies.

At present, we are not in the position to set our somewhat old-fashioned midparental height calculations aside and turn to the determination of specific genetic markers that would allow us to obtain a precise height prediction in a child. However, my personal anticipation is that the results of linkage studies in near future will find their way into the algorithms for height prediction in certain critical situations as their first practical application.

The results obtained so far, although they may seem disappointing to some of us, are promising considering the methodological limitations that are imposed by each of the approaches. After all, height and thereby growth is under a much stronger genetic control than most other complex traits. As such, the experience obtained by genetic studies in the physiology of growth may have an instrumental role for the study of other complex multi-gene disorders like obesity and high blood pressure.

\section{References}

1 Phillips K \& Matheny J. Quantitative genetic analysis of longitudinal trends in height: preliminary results from the Louisville twin study. Acta Geneticae Medicae et Gemellologiae 199039 143-163.

2 Preece MA. The genetic contribution to stature. Hormone Research 199645 56-58.

3 Silventoinen K, Kaprio J, Lahelma E \& Koskenvuo M. Relative effect of genetic and environmental factors on body height: differences across birth cohorts among Finnish men and women. American Journal of Public Health $200090627-630$.

4 Jepson A, Banya W, Hassan-King M, Sisay F, Bennett S \& Whittle H. Twin children in The Gambia: evidence for genetic regulation of physical characteristics in the presence of sub-optimal nutrition. Annals of Tropical Paediatrics 199414 309-313.

5 Vnencak-Jones CL, Phillips JA, III, Chen EY \& Seeburg PH. Molecular basis of human growth hormone gene deletions. PNAS 198885 5615-5619.

6 Parks JS, Abdul-Latif H, Kinoshita E, Meacham LR, Pfaffle RW \& Brown MR. Genetics of growth hormone gene expression. Hormone Research 199340 54-61.

7 Cogan JD, Phillips JA, III, Schenkman SS, Milner RD \& Sakati N. Familial growth hormone deficiency: a model of dominant and recessive mutations affecting a monomeric protein. Journal of Clinical Endocrinology and Metabolism 199479 1261-1265.

8 Cogan JD, Phillips JA, III, Sakati N, Frisch H, Schober E \& Milner RD. Heterogeneous growth hormone $(\mathrm{GH})$ gene mutations in familial GH deficiency. Journal of Clinical Endocrinology and Metabolism 1993 76 1224-1228.

9 Vivenza D, Guazzarotti L, Godi M, Frasca D, di Natale B, Momigliano-Richiardi P, Bona G \& Giordano M. A novel deletion in the $\mathrm{GH} 1$ gene including the IVS3 branch site responsible for autosomal dominant isolated growth hormone deficiency. Journal of Clinical Endocrinology and Metabolism 2006 91 980-986.

10 Wajnrajch MP, Gertner JM, Harbison MD, Chua SC, Jr \& Leibel RL. Nonsense mutation in the human growth hormone-releasing hormone receptor causes growth failure analogous to the little (lit) mouse. Nature Genetics 199612 88-90.

11 Wajnrajch MP. Genetic disorders of human growth. Journal of Pediatric Endocrinology and Metabolism 200215 (Suppl 2) 701-714.

12 Mullis P, Patel M, Brickell PM \& Brook CG. Isolated growth hormone deficiency: analysis of the growth hormone (GH)releasing hormone gene and the $\mathrm{GH}$ gene cluster. Journal of Clinical Endocrinology and Metabolism 1990 70 187-191.

13 Amselem S, Duquesnoy P, Attree O, Novelli G, Bousnina S, PostelVinay MC \& Goossens M. Laron dwarfism and mutations of the growth hormone-receptor gene. New England Journal of Medicine $1998321989-995$.

14 Goddard AD, Dowd P, Chernausek S, Geffner M, Gertner J, Hintz R, Hopwood N, Kaplan S, Plotnick L, Rogol A, Rosenfield R, Saenger P, Mauras N, Hershkopf R, Angulo M \& Attie K. 
Partial growth-hormone insensitivity: the role of growthhormone receptor mutations in idiopathic short stature. Journal of Pediatrics 1997131 51-55.

15 Woods KA \& Savage MO. Laron syndrome: typical and atypical forms. Baillieres Clinical Endocrinology and Metabolism 199610 371-387.

16 Kofoed EM, Hwa V, Little B, Woods KA, Buckway CK, Tsubaki J, Pratt KL, Bezrodnik L, Jasper H, Tepper A, Heinrich JJ \& Rosenfeld RG. Growth hormone insensitivity associated with a STAT5b mutation. New England Journal of Medicine 2003349 1139-1147.

17 Hwa V, Little B, Adiyaman P, Kofoed EM, Pratt KL, Ocal G, Berberoglu M \& Rosenfeld RG. Severe growth hormone insensitivity resulting from total absence of signal transducer and activator of transcription 5b. Journal of Clinical Endocrinology and Metabolism 200590 4260-4266.

18 Woods KA, Camacho-Hubner C, Barter D, Clark AJ \& Savage MO. Insulin-like growth factor I gene deletion causing intrauterine growth retardation and severe short stature. Acta Paediatrica. Supplement 1997423 39-45.

19 Abuzzahab MJ, Schneider A, Goddard A, Grigorescu F, Lautier C, Keller E, Kiess W, Klammt J, Kratzsch J, Osgood D, Pfaffle R, Raile K, Seidel B, Smith RJ \& Chernausek SD. IGF-I receptor mutations resulting in intrauterine and postnatal growth retardation. New England Journal of Medicine 2003349 2211-2222.

20 Unger S. IGF-I receptor mutations and intrauterine and postnatal growth retardation. New England Journal of Medicine 2004350 $1362-1363$.

21 Pfäffle RW, DiMattia GE, Parks JS, Brown MR, Wit JM, Jansen M, Van der Nat H, Van den Brande JL, Rosenfeld MG \& Ingraham HA. Mutation of the POU-specific domain of Pit-1 and hypopituitarism without pituitary hypoplasia. Science 1992257 1118-1121.

22 Wu W, Cogan JD, Pfaffle RW, Dasen JS, Frisch H, O'Connell SM, Flynn SE, Brown MR, Mullis PE, Parks JS, Phillips JA, III \& Rosenfeld MG. Mutations in PROP1 cause familial combined pituitary hormone deficiency. Nature Genetics 199818 147-149.

23 Dattani MT, Martinez-Barbera JP, Thomas PQ, Brickman JM, Gupta R, Martensson IL, Toresson H, Fox M, Wales JK, Hindmarsh PC, Krauss S, Beddington RS \& Robinson IC. Mutations in the homeobox gene HESX1/Hesx1 associated with septo-optic dysplasia in human and mouse. Nature Genetics 199819 125-133.

24 Netchine I, Sobrier ML, Krude H, Schnabel D, Maghnie M, Marcos E, Duriez B, Cacheux V, Moers A, Goossens M, Gruters A \& Amselem S. Mutations in LHX3 result in a new syndrome revealed by combined pituitary hormone deficiency. Nature Genetics 200025 182-186.

25 Machinis K, Pantel J, Netchine I, Leger J, Camand OJ, Sobrier ML, Dastot-Le Moal F, Duquesnoy P, Abitbol M, Czernichow P \& Amselem S. Syndromic short stature in patients with a germline mutation in the LIM homeobox LHX4. American Journal of Human Genetics 200169 961-968.

$26 \mathrm{Xu} \mathrm{J}$, Bleecker ER, Jongepier H, Howard TD, Koppelman GH, Postma DS \& Meyers DA. Major recessive gene(s) with considerable residual polygenic effect regulating adult height: confirmation of genomewide scan results for chromosomes 6, 9, and 12. American Journal of Human Genetics 200271 646-650.

27 Hirschhorn JN, Lindgren CM, Daly MJ, Kirby A, Schaffner SF, Burtt NP, Altshuler D, Parker A, Rioux JD, Platko J, Gaudet D, Hudson TJ. Groop LC \& Lander ES. Genomewide linkage analysis of stature in multiple populations reveals several regions with evidence of linkage to adult height. American Journal of Human Genetics 2001 69 106-116.

28 Deng HW, Xu FH, Liu YZ, Shen H, Deng H, Huang QY, Liu YJ, Conway T, Li JL, Davies KM \& Recker RR. A whole-genome linkage scan suggests several genomic regions potentially containing QTLs underlying the variation of stature. American Journal of Medical Genetics $200211329-39$.

29 Perola M, Hman M, Hiekkalinna T, Vuori J, Pajukanta P, Wessman M, Koskenvuo M, Palotie A, Lange K, Kaprio J \& Peltonen L. Quantitative-trait-locus analysis of body-mass index and of stature, by combined analysis of genome scans of five Finnish study groups. American Journal of Human Genetics 200169 $117-123$.

30 Liu YZ, Xiao P, Guo YF, Xiong DH, Zhao LJ, Shen H, Liu YJ, Dvornyk V, Long JR, Deng HY, Li JL, Recker RR \& Deng HW. Genetic linkage of human height is confirmed to 9q22 and Xq24. Human Genetics 2006119 295-304.

31 Afzal AR, Rajab A, Fenske CD, Oldridge M, Elanko N, TernesPereira E, Tuysuz B, Murday VA, Patton MA, Wilkie AO \& Jeffery S. Recessive Robinow syndrome, allelic to dominant brachydactyly type B, is caused by mutation of ROR2. Nature Genetics 2000 25 419-422.

32 Afzal AR \& Jeffery S. One gene, two phenotypes: ROR2 mutations in autosomal recessive Robinow syndrome and autosomal dominant brachydactyly type B. Human Mutatation $2003221-11$.

33 Hintz RL. SHOX mutations. Reviews in Endocrine and Metabolic Disorders 20023 363-367.

34 Cardon LR \& Bell JI. Association study designs for complex diseases. Nature Reviews. Genetics 20012 91-99.

35 Tabor HK, Risch NJ \& Myers RM. Candidate-gene approaches for studying complex genetic traits: practical considerations. Nature Reviews. Genetics 20023 391-397.

36 Hirschhorn JN, Lohmueller K, Byrne E \& Hirschhorn K. A comprehensive review of genetic association studies. Genetics in Medicine: Official Journal of the American College of Medical Genetics 20024 45-61.

37 Vaessen N, Heutink P, Janssen JA, Witteman JC, Testers L, Hofman A, Lamberts SW, Oostra BA, Pols HA \& Van Duijn CM. A polymorphism in the gene for IGF-I: functional properties and risk for type 2 diabetes and myocardial infarction. Diabetes 200150 637-642.

38 Vaessen N, Janssen JA, Heutink P, Hofman A, Lamberts SW, Oostra BA, Pols HA \& Van Duijn CM. Association between genetic variation in the gene for insulin-like growth factor-I and low birthweight. Lancet $2002 \mathbf{3 5 9} 1036-1037$.

39 Frayling TM, Hattersley AT, McCarthy A, Holly J, Mitchell SM, Gloyn AL, Owen K, Davies D, Smith GD \& Ben Shlomo Y. A putative functional polymorphism in the IGF-I gene: association studies with type 2 diabetes, adult height, glucose tolerance, and fetal growth in UK populations. Diabetes 200251 2313-2316.

40 Arends N, Johnston L, Hokken-Koelega A, van Duijn C, de Ridder M, Savage M \& Clark A. Polymorphism in the IGF-I gene: clinical relevance for short children born small for gestational age (SGA). Journal of Clinical Endocrinology and Metabolism 2002872720.

41 Pantel J, Machinis K, Sobrier ML, Duquesnoy P, Goossens M \& Amselem S. Species-specific alternative splice mimicry at the growth hormone receptor locus revealed by the lineage of retroelements during primate evolution. Journal of Biological Chemistry 2000275 18664-18669.

42 Dos Santos C, Essioux L, Teinturier C, Tauber M, Goffin V \& Bougneres P. A common polymorphism of the growth hormone receptor is associated with increased responsiveness to growth hormone. Nature Genetics 200436 720-724.

43 Binder G, Baur F, Schweizer R \& Ranke MB. The d3-growth hormone $(\mathrm{GH})$ receptor polymorphism is associated with increased responsiveness to GH in Turner syndrome and short small-forgestational-age children. Journal of Clinical Endocrinology and Metabolism 200691 659-664.

44 Jorge AA, Marchisotti FG, Montenegro LR, Carvalho LR, Mendonca BB \& Arnhold IJ. Growth hormone (GH) pharmacogenetics: influence of GH receptor exon 3 retention or deletion on first-year growth response and final height in patients with severe GH deficiency. Journal of Clinical Endocrinology and Metabolism 200691 1076-1080.

Received 30 April 2006

Accepted 21 June 2006 